УДК 624.074:[624.012.4+624.014.2]

\title{
CALCULATION OF COMPRESSED AND BENDED STEEL REINFORCED CONCRETE CONSTRUCTIONS IN THE RETAINED FORMWORK
}

Dr. techn. science O. Lapenko, postgraduate D. Skrebnieva, O. Shevchenko, N. Masud

\section{РОЗРАХУНОК СТИСНУТИХ І ЗІГНУТИХ СТАЛЕЗАЛІЗОБЕТОННИХ} КОНСТРУКЩЙ У НЕЗНІМНІЙ ОПАЛУБЦІ

Д-р техн. наук О. І. Лапенко, аспіранти Д. С. Скребнєва, О. В. Шевченко, Н. Н. Масуд

\section{РАСЧЁТ СЖАТЫХ И СОГНУТЫХ СТАЛЕЖЕЛЕЗОБЕТОННЫХ КОНСТРУКЦИЙ В НЕСЪЕМНОЙ ОПАЛУБКЕ}

Д-р техн. наук А. И. Лапенко, аспиранты Д. С. Скребнева, О. В. Шевченко, Н. Н. Масуд

The problems of calculation of compressed and bended steel reinforced concrete structures in the retained formwork were considered. Apart it's necessary to consider the questions which are related with calculation tube concrete tube structures. As the role of steel tube in the tube concrete reduced mainly to reduced of transversal expanding of concrete core at the element compression, 
but from the theory of concrete strength it's known, that with the increasing of transversal compression the strength of concrete may increase significantly, then a major role in bearing capacity tube concrete element must perform work steel pipe in the transverse direction.

The method is developed in the compressed elements from steel i-sections with lateral cavities, fulled by concrete. The method of calculation by the deformed scheme is more accurately express the real picture of elements deformation.

The method of calculating of bending reinforced concrete elements in non-removable formwork to a transverse force. The conclusion of the feasibility of using the calculated deformation model that best corresponds to the real work of load bearing structures was made.

The program of calculation of the computer, which provides a satisfactory convergence with experimental data is composed by the developed methodology.

Key words: steel reinforced concrete constructions, steel tube, retained formwork, stressstrain state.

Розглянуто питання розрахунку стиснутих $i$ зігнутих сталезалізобетонних конструкиій у незнімній опалубиі. Зроблено висновок про доцільність використання розрахункової деформаційної моделі, яка найкраще відповідає реальній роботі несучих конструкиій.

Ключові слова: сталезалізобетонні конструкиї, трубобетон, незнімна опалубка, напружено-деформований стан.

Рассмотрены вопросы расчета сжатых и изогнутых сталежелезобетонных конструкиий в несъемной опалубке. Сделан вывод о целесообразности использования расчетной деформационной модели, которая наилучшим образом соответствует реальной работе несущих конструкций.

Ключевые слова: сталежелезобетонные конструкиии, трубобетон, несъемная опалубка, напряженно-деформированное состояние.

Introduction. Reinforced concrete structures in the retained formwork are different [8]. Besides design characteristics (reinforcing by tubes, sheets or rolling sections, profiled sheets), purpose (columns, beams, slabs), they are differed by stressed state (central or noncentral comression, bending). For today, there are many ways of calculation of reinforced concrete structures, which provide a certain degree of reliability in the operation. Calculation of reinforced concrete structures in the retained formwork can be performed by the next methods:

- with using of calculated deformation model;

- with using of boundary efforts in the concrete, reinforcement and steel, based on their plastic work;

- by resulted to steel section.
The numerical calculations of load bearing capacity structures with using of method of finite elements with the help of computers are enough deeply developed and widely spread at the given time. The problems of calculation of reinforced concrete structures are considered in the international normative document Eurocode 4 [2].

Materials and methods. Apart it's necessary to consider the questions which are related with calculation tube concrete tube structures. As the role of steel tube in the tube concrete reduced mainly to reduced of transversal expanding of concrete core at the element compression, but from the theory of concrete strength it's known, that with the increasing of transversal compression (lateral pressure) the strength of concrete may increase significantly, then a major role in bearing capacity tube concrete element must perform 
work steel pipe in the transverse direction. This can be achieved by adjusting the geometrical and mechanical parameters tube concrete element. For example, tube concrete elements with thin-walled steel pipes more efficient because in the result of powerful effect of these elements the steel pipe resists only in the transverse direction. That's why in the general case at the calculation of compressed tube concrete elements it's necessary to use the formula

$$
N=\alpha R_{b} A_{b}+\beta R_{s} A_{s},
$$

where $R_{b} A_{b}$ - bearing capacity of concrete core at compression;

$R_{s} A_{s}$ - bearing capacity in compression of steel tube;

$\alpha, \beta-$ corrective coefficients.

The proposed methods of factors determining the efficiency of steel and concrete $\alpha$, and $\beta$ based on theorems and postulates of mechanics of solid deformable environment, primarily on the methods of the theory of plasticity and strength theory [7]. They take into account the peculiarity of tube concrete element work of element as internally static undetermined system and peculiarities of steel tube resistance, that can be thin-walled (resistance only in the transverse direction), as well as thick-walled (resistance in transverse and longitudinal direction).

Mathematical apparatus of fundamental methods is the most structural. He completely, and the integral part of the calculated bearing capacity of steel tube element has a clear physical meaning and requires the use of empirical coefficients. Therefore, the fundamental methods are universal, with high precision and have a perfect analytical completed form.

It completely and by the separate parts of calculated load-bearing capacity of the tube concrete element has a clear physical meaning and doesn't require the use of empirical coefficients. Therefore, the fundamental methods are universal, with high accuracy and have a perfect analytical completed view.

At calculating noncentral compressed elements are used the condition:

$$
\begin{aligned}
& N_{p b}=\frac{2 \sigma_{z s}^{\prime} r t_{s}}{1+\cos \alpha} \int_{\alpha}^{\gamma}(\cos \alpha-\cos \beta) d_{b} \beta+2 \sigma_{z s}^{\prime} r t_{s} \int_{\gamma}^{\pi} d_{b} \beta+2 \sigma_{z b}^{\prime} r^{2} \int_{\gamma}^{\pi} \sin ^{2} \beta^{2} d_{b}- \\
& -\frac{2 \sigma_{y} r t_{s}}{1+\cos \alpha} \int_{0}^{\alpha}(\cos \beta-\cos \alpha) d_{b} \beta+\frac{2 \sigma_{z b}^{\prime} r^{2}}{1+\cos \alpha} \int_{\alpha}^{\gamma}(\cos \alpha-\cos \beta) \sin ^{2} \beta^{2} d_{b}
\end{aligned}
$$

where $N_{p b}$ - bearing capacity tube concrete element;

$$
\begin{aligned}
& \sigma_{y} \text { - boundary of fluidity metal pipe; } \\
& r-\text { middle radius of tube; } \\
& t_{s}-\text { thickness of wall of tube shell. }
\end{aligned}
$$

The position of neutral axis (value of angle $\alpha$ ) is calculated from condition:

$$
e_{0}+r \cos \alpha=M / N
$$

Method of determining the stress-strain state of steel concrete elements with sheet reinforcement under axial compression based on experimental researches of centrally compressed samples. It is believed that the metal and concrete reliably "welded" and throught this limit is the impact of one component of the transversal cross section of the others. From the schedules of dependence of longitudinal and transverse strains on the load revealed that they have a curvilinear nature, it means that prototypes work both in elastic $(\approx 60 \%$ of the destructive effort) and a plastic stage. Therefore, these two stages of prototypes are considered separately.

In the elastic stage the longitudinal and transverse stresses can be determined by the 
general formulas of Hooke's law equations that have the view

$$
\begin{gathered}
\sigma_{x}=2 G\left(\varepsilon_{x}+\frac{3 v}{1-2 v} \varepsilon_{c p}\right) \\
\sigma_{y}=2 G\left(\varepsilon_{y}+\frac{3 v}{1-2 v} \varepsilon_{c p}\right) \\
\sigma_{z}=2 G\left(\varepsilon_{z}+\frac{3 v}{1-2 v} \varepsilon_{c p}\right),
\end{gathered}
$$

where $\varepsilon_{x}, \varepsilon_{y}, \varepsilon_{z}-$ deformation along respective axes;

$$
\sigma_{x}, \sigma_{y}, \sigma_{z}-\text { tension along respective }
$$

axes;

$$
\begin{gathered}
G=\frac{E_{i}}{2\left(1+v_{i}\right)} ; \\
\varepsilon_{c p}=\frac{\varepsilon_{x}+\varepsilon_{y}+\varepsilon_{z}}{3} ;
\end{gathered}
$$

$E_{i}, v_{i}-$ modulus of elasticity and coefficient of transverse deformation of the imaterial;

$i=s, s 1, b-$ materials, which consisted the transversal cross-section.

In the case, when the dependence of the deformations from the loads obtain the curvilinear nature due to the development of elastic and plastic deformations, stresses are determined using the theory of small elasticplastic strains. In this case, the relationship between the individual components of stresses and strains by the form is the analogical to elastic stage, but with the replacement of constant modulus of elasticity $\mathrm{E}$ on variable strain module $E^{\prime}$. According to this method it was compiled the calculation program for PC.

The method is developed in the compressed elements from steel i-sections with lateral cavities, fulled by concrete. The method of calculation by the deformed scheme is more accurately express the real picture of elements deformation. It admits the work of compressed elements in the stress strain state before the moment of the achievement of boundary deformations. According to this method the scheme of deformation of geometrical elements axis under the action of load with taking into account of physical and mechanical characteristics of every elementary part of steel i-section, rod reinforcement of concrete is defined.

Calculations of steel reinforced concrete compresssed elements with taking into account of deformation model of transversal crosssection elements include:

- equation of equilibrium of external and internal forces in the normal cross-section;

- conditions of normal section deformation;

- diagrams of state (deformation) of concrete, rebar, steel.

To determine the stress-strain state in the normal section two known equilibrium equations are used:

- equilibrium equation of projection of forces on the longitudinal axis of structure;

- the equation of equilibrium of moments in respect of any chosen axis in the section of structure that is perpendicular to the plane of action of bending moment.

At the calculating of steel concrete structures in general case the structure crosssection is considered as a set $m$ of elementary sections of concrete (with index $i$ ), of $p$ reinforcement rods (with index $k$ ) and of $n$ elementary areas of steel part of structures (with index $j$ ). In this case, the equilibrium equations are:

$$
\mathrm{N}-\sum_{i=1}^{m} \sigma_{b i} A_{b i}-\sum_{j=1}^{n} \sigma_{r j} A_{r j}-\sum_{k=1}^{p} \sigma_{s k} A_{s k}=\mathbf{0}
$$




$$
N e-\sum_{i=1}^{m} \sigma_{b i} A_{b i} y_{b i}-\sum_{j=1}^{n} \sigma_{r j} A_{i j} y_{r j}-\sum_{k=1}^{p} \sigma_{s k} A_{s k} y_{s k}=0
$$

where $N$ - external longitudinal force; $e$ distance from the force $N$ to selected axis $O-O$, that is located in the limits of structure crosssection corresponding to which the moments of internal forces in the concrete, steel and reinforcement with taking into account bending are determined;

$$
A_{b i}, A_{r j}, A_{s k} \text { - area of elementary areas }
$$
according to concrete, steel and reinforcement;

$$
y_{b i}, y_{r j}, y_{s k} \text { - distance from the selected }
$$
torque axis to the center of gravity of elementary sections (according to concrete, steel and reinforcement);

$\sigma_{b i}, \quad \sigma_{r j}, \sigma_{s k}$ - stress on elementary areas under concrete and steel reinforcement.

Condition of deformation of the normal structure section is taken as a plane of rotation of the linear strain distribution by the height of the section from the considerated impacts.

At calculating of efforts in the section of compressed steel reinforced concrete element of stresses in concrete, reinforcement and steel are defined by the deformations with help of state of materials diagrams which are associated stresses with deformations. State diagrams are presented in the form of noded (basic) points that define the most characteristic stages of stress-strain state materials. Parameters of base point of diagrams of materials state are normative resistances of materials and the corresponding to it the strains. The value of parameters of additional basic points are defined as derived from the parameters of main base point.

Parameters base point that corresponds to the elastic limits of fittings, assumed to be the current resistance fittings and its corresponding strain:

Parameters of main base point that corresponds to the limit of elastic work of reinforcement, assumed to be the equal to the calculated resistance of reinforcement $\sigma_{s o}=R_{s}$ and its corresponding strain:

$$
\varepsilon_{s o}=\frac{R_{s}}{E_{s}},
$$

where $E_{s}$ - modulus of elasticity of reinforcement.

The similar values of parameters of base points and calculated dependenaes are assumed for steel. State diagrams of steel and reinforcement in tension and compression are assumed equal.

Calculation of compressed steel reinforced concrete elements can be done by boundary efforts with use of two equilibrium conditions.

The methods of reinforced concrete structures in non-removable formwork that work on a bend for all types of cross-sections that are discussed in [1]. So at consideration of stress-strain state of reinforced concrete elements with an external sheet reinforcement the preconditions are accepted and known:

- follows to the hypothesis of flat sections;

- follows to the static condition:

$$
\sum N_{i}=0 ; \quad \sum M_{i}=0 ;
$$

- resistance of concrete in tension is assumed to be zero;

- resistance of concrete on compression stresses conditionaly is represented by stress thatequals $R_{b}$, (multiplied, in the necessary cases by a factor of work conditions), evenly distributed over the part of the compressed area;

- tensile strain in sheet and rod reinforcement are assumed not more than calculated tensile resistance $R_{y}$ and $R_{s c}$, 
multiplied, in the necessary case by a factor of working conditions;

- compressive stresses in the sheet and rod reinforcement are assumed not more than the calculated resistances to compression and $R_{y}$ and $R_{s c}$ multiplied if necessary by a factor working conditions.

At approach of beams on bend destruction took place on a normal section. The reason was achievement of stresses of fracture yield strength steel bars and detachment vertical reinforcement sheet with further destruction of the concrete in the compressed zone section. Evaluation of the strength elements on the boundary conditions for the destruction of these forms can be presented on the basis of joint decisions longitudinal balance of forces depending on the scheme of internal efforts. In this case, the design scheme is considered normal cross section (Figure 1, Figure 2).

At experiment of beams on bend of destruction took place on a normal section. The reason of distruction was to achieve stress of yield strength steel reinforcement and detachment of vertical sheet reinforcement with further destruction of the concrete in the compressed zone of section. Evaluation of the strength elements on the boundary conditions for the destruction of these forms can be presented on the basis of mutual decision of equilibrium of longitudinal force depending on the scheme of internal efforts. In this case, the design scheme of normal cross section is considered (Figure 1, Figure 2).

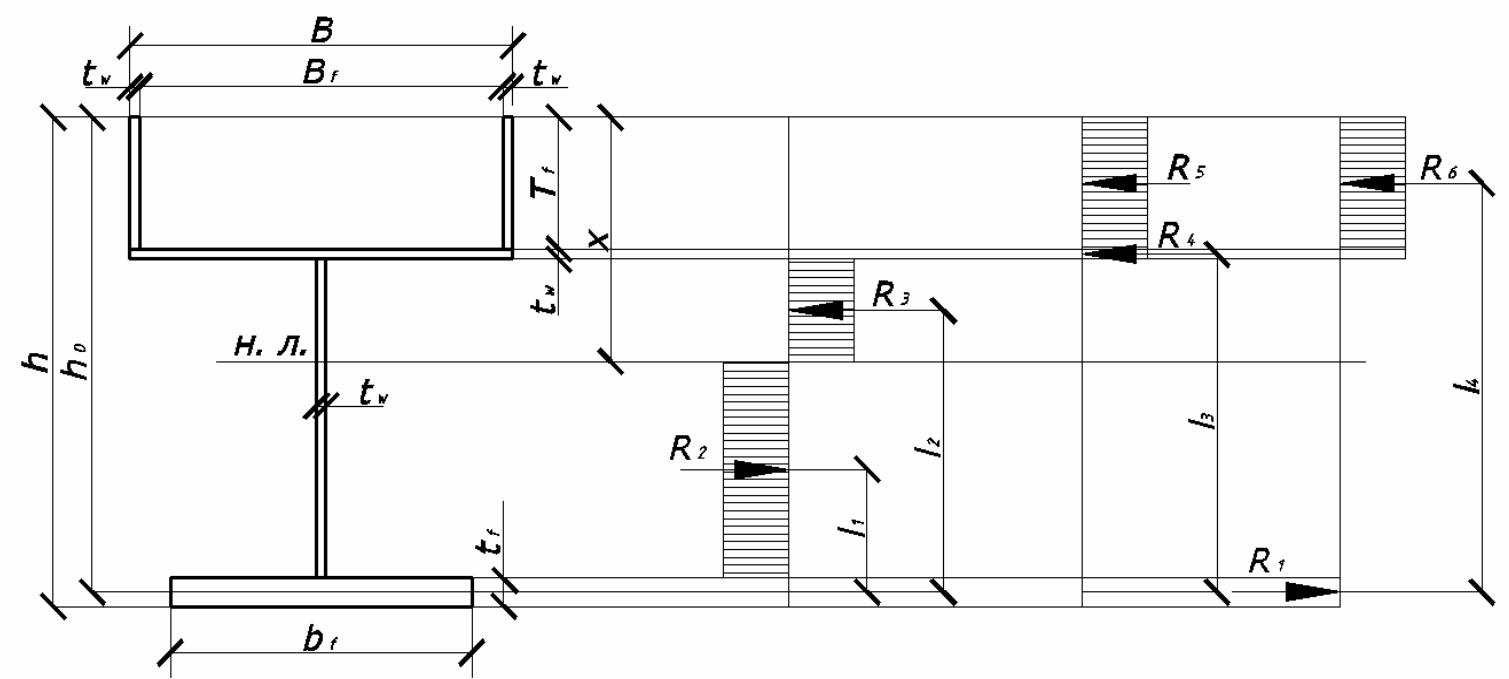

Fig. 1. Diagram of internal efforts in the normal section

The conditions of static (7):

$$
\begin{aligned}
& R_{y}\left(t_{\omega}\left(h-t_{f}-2 x+T_{f}+t_{w}-B\right)-T_{f}\left(B-B_{f}\right)+R_{y}^{\prime} b_{f} t_{f}-R_{b} B_{f} T_{f}=0 .\right. \\
& M_{p} \leq T_{f}\left(R_{y}\left(B-B_{f}\right)+R_{b} B_{f}\right) \times\left(h_{0}-0,5 t_{f}\right)+R_{y} t_{w}\left(B\left(h_{0}-T_{f}-0,5 t_{w}\right)+\right. \\
& +\left(x-T_{f}-t_{w}\right)\left(h_{0}-T_{f}-t_{w}-0,5 \times\left(x-T_{f}-t_{w}\right)\right)-\left(h-t_{f}-x\right)\left(h_{0}-x-\right. \\
& \left.-0,5\left(h_{0}-x-0,5 t_{f}\right)\right) .
\end{aligned}
$$



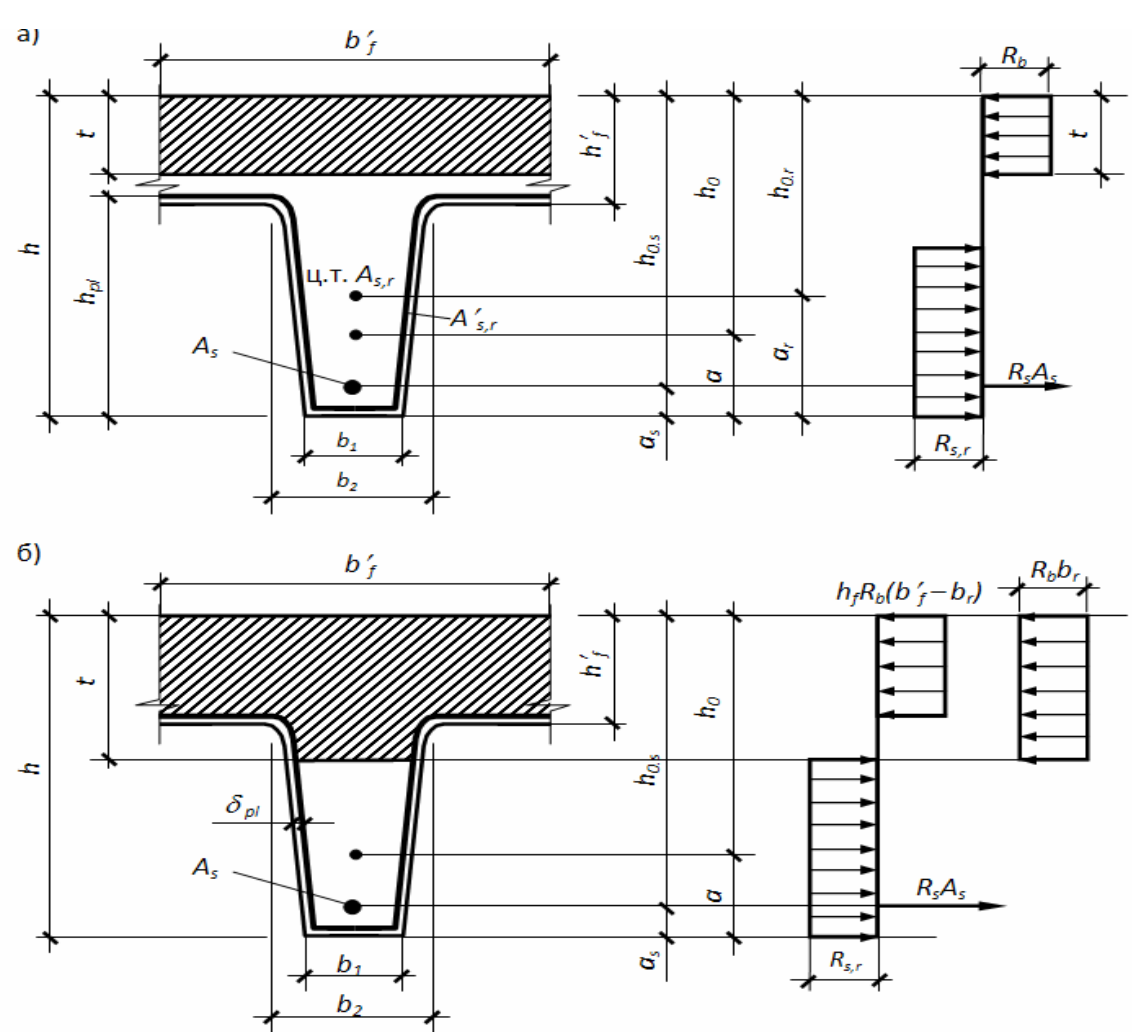

Fig. 2. I-section transversal sections and their calculated scheme:

$a$ - neutral line within the shelf; $\sigma$ - neutral line within the shelf of $i$-section edge

The method of calculating of bending reinforced concrete elements in non-removable formwork to a transverse force. The calculation of elements with sheet reinforcement should use by the formula:

$$
Q_{u} \leq \frac{\varphi_{b 4} R_{b t} b h_{0}^{2}}{c}+2 R_{y w} t_{w} c
$$

To calculate the movement of the bending concrete elements in non-removable formwork is received by the formula:

$$
f_{M}=\frac{M_{p o 3}}{0,85 \cdot I_{r e d} \cdot E_{s}} \cdot\left(\frac{3 l^{2}-4 a^{2}}{24}\right) \text {. }
$$

The proposed formulas for calculating anchor means to ensure the mutual operation of concrete and steel in reinforced concrete structures in non-removable formwork.

Conclusion. The developed algorithms of calculation allow to calculate with sufficient accuracy to determine the efforts of destruction and curvature of steel reinforced concrete pillars, beams and floor slabs and reflect the distribution of strains and stresses not only in concrete but also in steel reinforcement. The program of calculation of the computer, which provides a satisfactory convergence with experimental data is composed by the developed methodology.

\section{References}

1. Babych, E. E. Porivnjannja vyznachennja napruzheno-deformovanogo stysnuto-zignutyh zalizobetonnyh elenentiv z vykorystannjam riznyh diagram deformuvantja betonu / E.E. Babych // Resursoekonomichni materialy, konstruktsii, budivli ta sporudy: zb. Naukovyh prats`. - Rivne: NUVHP, 2009. - Vyp. 16. Ch.2. 
2. Eurocod 4. Common Unified Rules for Composite Steel and concrete Structures European Committee for Standardization. (CEN) ENV. 1994 - 1-1:1992. - 180 p.

3. Fan J. Long-Term Behavior of Composite Beams under Positive and Negative Bending. I: Experimental Study / J. Fan, J. Nie, Q. Li, H. Wang // Journal of Structural Engineering. - Vol. 136. - 2010. - No. 7. - P. 849-857.

4. Flaga, K. On crack development in reinforced slab of steel concrete composite beams / K. Flaga, K. Furtak // Visnyk Natsionalnogo Universytetu «Lvivska politehnika». Teorija i praktika. - №664. - Lviv, 2010. - P. 378-386.

5. Steel-concrete composite structures proceeding of the 4 - international conference. Kosice Slovakia. - June 1994.

6. Storozhenko, L. I. Experimental research of bendable framings made from Steel double-T with cavity filled with concrete / L.I. Storozhenko, S.V. Yakhin, O.V. Nizhnik // XLIX Conferences Naukowa. - Krunica, 2003. - P. 237-244.

7. Storozhenko, L. I. Stalezalizobetonni konstruktsii / L.I. Storozhenko, O.V. Semko, V.F. Pents // Poltava: 2005. - 181 s.

8. Storozhenko, L. I. Zalizobetonni konstruktsii v neznimniy opalubtsi / L.I. Storozhenko, O.I. Lapenko // Poltava: ASMI, 2008. - 312 s.

Лапенко Олександр Іванович, д-р техн. наук, професор, Національний авіаційний університет, Навчальнонауковий інститут аеропортів, завідувач кафеди комп'ютерних технологій будівництва. Тел.: (044)406-71-60, +38(067)-234-79-99. E-mail: my-partner@ukr.net.

Скребнєва Дарія Сергіївна, аспірантка, Національний авіаційний університет, Навчально-науковий інститут аеропортів, кафедра комп’ютерних технологій будівництва. Тел. (044) 406-74-24, +38(093)-199-48-35.

E-mail: jellybon1111@gmail.com.

Шевченко Олександра Володимирівна, аспірантка, Національний авіаційний університет, Навчально-науковий інститут аеропортів, кафедра комп'ютерних технологій будівництва. Тел.(044)406-74-24, +38(098)-075-34-99. E-mail: brygantina@mail.ru.

Масуд Надім Нурович, аспірант, Національний авіаційний університет, Навчально-науковий інститут аеропортів, кафедра комп'ютерних технологій будівництва. Тел.(044)406-74-24, +38(073)-484-43-33.

E-mail: olimppzb@ukr.net.

Lapenko Olexander, Dr. techn. science, professor, National Aviation University, Educational-Scientific Institute of Airports, Computer Technologies of Construction Department. Tel.: (044) 406-71-60, +38(067)-234-79-99.

E-mail: my-partner@ukr.net.

Skrebnieva Dariia, postgraduate, National Aviation University, Educational-Scientific Institute of Airports, Computer Technologies of Construction Department. Tel.: (044) 406-74-24, +38(093)-199-48-35.

E-mail: jellybon1111@gmail.com.

Shevchenko Olexandra, postgraduate, National Aviation University, Educational-Scientific Institute of Airports,

Computer Technologies of Construction Department. Tel.: (044) 406-74-24, +38(098)-075-34-99.

E-mail: brygantina@mail.ru.

Masud Nadim, postgraduate, National Aviation University, Educational-Scientific Institute of Airports, Computer Technologies of Construction Department.Tel.(044)406-74-24,+38(073)-484-43-33.E-mail: olimppzb@ukr.net.

Стаття прийнята 20.04.2017 p. 